\title{
Do syntopic host species harbour similar symbiotic communities? The case of Chaetopterus spp. (Annelida: Chaetopteridae)
}

\author{
Temir A Britayev ${ }^{1}{ }^{\text {, Elena Mekhova }}{ }^{1}{ }^{\text {, }}$ Yuri Deart ${ }^{1}{ }^{\text {, }}$ Daniel Martin ${ }^{\text {Corresp. }}{ }^{2}$ \\ ${ }^{1}$ Severtzov Institute of Ecology and Evolution, Russian Academy of Sciences, Moscow, Moscow, Russian Federation \\ 2 Department of Marine Ecology, Centre d'Estudis Avançats de Blanes (CEAB - CSIC), Blanes, Catalunya, Spain \\ Corresponding Author: Daniel Martin \\ Email address: dani@ceab.csic.es
}

To assess whether closely related host species harbour similar symbiotic communities, we studied two polychaetes, Chaetopterus sp. $(n=11)$ and Chaetopterus cf. appendiculatus ( $n=83$ ) living in soft sediments of Nhatrang Bay (South China Sea, Vietnam). The former harboured the porcellanid crabs Polyonyx cf. heox and Polyonyx sp., the pinnotherid crab Tetrias sp. and the tergipedid nudibranch Phestilla sp. The latter harboured the polynoid polychaete Ophthalmonoe pettiboneae, the carapid fish Onuxodon fowleri and the porcellanid crab Eulenaios cometes, all of which, except $O$. fowleri, seemed to be specialized symbionts. The species richness and mean intensity of the symbionts were higher in Chaetopterus sp. than in C. cf. appendiculatus (1.8 and 1.02 species and 3.0 and 1.05 individuals per host respectively). We suggest that the lower density of Chaetopterus sp. may explain the higher number of associated symbionts observed, as well as the $100 \%$ prevalence (69.5\% in C. cf. appenciculatus). Most Chaetopterus sp. harboured two symbiotic species, which was extremely rare in C. cf. appendiculatus, suggesting lower interspecific interactions in the former. The crab and nudibranch symbionts of Chaetopterus sp. often shared a host and lived in pairs, thus partitioning resources. This led to the species coexisting in the tubes of Chaetopterus sp., establishing a tightly packed community, indicating high species richness and mean intensity, together with a low species dominance. In contrast, the aggressive, strictly territorial species associated with C. cf. appendiculatus established a symbiotic community strongly dominated by single species and, thus, low species richness and mean intensity. Therefore, we suggest that interspecific interactions are determining species richness, intensity and dominance, while intraspecific interactions are influencing only intensity and abundance. It is possible that species composition may have influenced the differences in community structure observed. We hypothesize that both host species could originally be allopatric. The evolutionary specialization of the symbiotic communities would occur in separated 
geographical areas, while the posterior disappearance of the existing geographical barriers would lead to the overlapped distribution. 
1 Do syntopic host species harbour similar symbiotic communities? The case of

2 Chaetopterus spp. (Annelida: Chaetopteridae)

3 Temir A. Britayev*, Elena Mekhova*, Yury Deart* and Daniel Martin**

4 *Severtzov Institute of Ecology and Evolution, Russian Academy of Sciences, Moscow, Russia.

5 E-mail: britayev@yandex.ru

6 ** Department of Marine Ecology, Centre d'Estudis Avançats de Blanes (CEAB - CSIC), Blanes,

7 Catalunya, Spain. E-mail: dani@ceab.csic.es

8 Abstract

9 To assess whether closely related host species harbour similar symbiotic communities, we 10 studied two polychaetes, Chaetopterus sp. $(\mathrm{n}=11)$ and Chaetopterus cf. appendiculatus $(\mathrm{n}=83)$

11 living in soft sediments of Nhatrang Bay (South China Sea, Vietnam). The former harboured the

12 porcellanid crabs Polyonyx cf. heox and Polyonyx sp., the pinnotherid crab Tetrias sp. and the

13 tergipedid nudibranch Phestilla sp. The latter harboured the polynoid polychaete Ophthalmonoe

14 pettiboneae, the carapid fish Onuxodon fowleri and the porcellanid crab Eulenaios cometes, all of

15 which, except $O$. fowleri, seemed to be specialized symbionts. The species richness and mean

16 intensity of the symbionts were higher in Chaetopterus sp. than in C. cf. appendiculatus (1.8 and

171.02 species and 3.0 and 1.05 individuals per host respectively). We suggest that the lower

18 density of Chaetopterus sp. may explain the higher number of associated symbionts observed, as

19 well as the $100 \%$ prevalence (69.5\% in C. cf. appenciculatus). Most Chaetopterus sp. harboured

20 two symbiotic species, which was extremely rare in C. cf. appendiculatus, suggesting lower

21 interspecific interactions in the former. The crab and nudibranch symbionts of Chaetopterus $\mathrm{sp}$.

22 often shared a host and lived in pairs, thus partitioning resources. This led to the species

23 coexisting in the tubes of Chaetopterus sp., establishing a tightly packed community, indicating

24 high species richness and mean intensity, together with a low species dominance. In contrast, the

25 aggressive, strictly territorial species associated with $C$. cf. appendiculatus established a

26 symbiotic community strongly dominated by single species and, thus, low species richness and

27 mean intensity. Therefore, we suggest that interspecific interactions are determining species 
28 richness, intensity and dominance, while intraspecific interactions are influencing only intensity

29 and abundance. It is possible that species composition may have influenced the differences in

30 community structure observed. We hypothesize that both host species could originally be

31 allopatric. The evolutionary specialization of the symbiotic communities would occur in

32 separated geographical areas, while the posterior disappearance of the existing geographical

33 barriers would lead to the overlapped distribution.

\section{1.- Introduction}

During the last few decades, significant efforts have been undertaken to study the species composition and structure of marine symbiotic communities associated with different hosts taxa such as scleractinian corals (Hoeksema et al. 2012; Stella et al. 2010), echiurans (Anker et al. 2005), hermit crabs (Williams \& McDermott 2004) and echinoderms (Barel \& Kramers 1977). Despite this being an interesting aspect of marine ecosystems' functioning and the need to fill in existing gaps in related knowledge, the current focus of scientific interests have shifted to ecological and evolutionary aspects of the establishment of symbiotic communities (Baeza 2015; Duffy 2002; Thiel \& Baeza 2001). Accordingly, host characteristics (morphological, ecological and physiological) have been considered as some of the most important parameters driving these processes (e.g., Abele \& Patton 1976; Deheyn et al. 2006; Goto \& Kato 2011).

The coexistence of potential hosts that are taxonomically closely related taxonomically (thus sharing similar morphological and physiological characteristics) may facilitate host switching, leading to the infestation of different host species by the same species of symbiont, as reported for example in freshwater fish (Poulin 1998). Accordingly, we may expect the composition of symbiotic communities established on closely related hosts to be similar. Hence, sympatric coral species belonging to the same family harbour symbiotic communities more similar than those belonging to different families (Stella et al. 2010), while the symbiotic communities associated with two starfish hosts from the same family living in the same area have nearly identical species composition (Antokhina et al. 2012). There seems to be a correlation between increasing taxonomic proximity between hosts and a higher similarity in species composition of the respective symbiotic communities. In other words, we could expect that closely related (i.e., belonging to the same genus) host species sharing the same habitat would harbour very similar (or even identical) symbiotic communities. Therefore, the current study 
58 investigated the symbiotic communities associated with two species of Chaetopterus in Nhatrang

59 Bay (Vietnam), to assess whether this hypothesis may apply to this particular situation.

60 These two species of Chaetopterus appeared to be excellent subjects for the intended 61 comparison due to their highly similar morphology. In fact, the genus has long been long 62 regarded as monospecific and, to date, the morphological identification of species is still 63 considered as rather complex (Britayev \& Martin 2016; Nishi et al. 2009; Petersen 1984a; 64 Petersen 1984b). Moreover, these two species share the same habitat and, thus the influence of environmental parameters can be excluded as influential factors on the associated symbiotic communities.

The genus Chaetopterus (Annelida: Chaetopteridae) includes relatively large animals (up to $20-25 \mathrm{~cm}$ in length) living in roughly U-shaped tubes embedded into soft sediments or attached to hard surfaces in shallow waters of temperate and tropical seas (Britayev \& Martin 2016). Morphologically, they are highly adapted for feeding on plankton using complex mucus-net based mechanisms (Enders 1909). They are also well known as hosts harbouring numerous symbiotic associates (often including complex communities) inside their parchment-like tubes. These tubes provide well-protected shelter with continuous water flow bringing oxygen and food items to the symbionts (Britayev \& Martin 2016). To date, approximately 28 species of symbionts have been reported living inside tubes of Chaetopterus (Britayev 1993). However, information on the composition of associated communities is lacking, and is currently only available for two species, C. pergamentaceus Cuvier, 1830 and C. cf. cautus Marenzeller, 1879, which are each host to 3-5 species of crabs and polychaetes (Britayev 1993; Gray 1961).

A species of Chaetopterus (not confirmed but probably Chaetopterus cf. appendiculatus Grube, 1874) inhabiting Vietnamese soft seabed sediments was previously reported as harbouring three species of symbionts within its tubes: the polychaete Ophthalmonoe pettiboneae Petersen \& Britayev 1997, an unidentified carapid fish and a porcellanid crab (Britayev \& Martin 2005). The presence of a second, probably undescribed, species of Chaetopterus sharing the same habitat and having its own associated symbiotic community allowed us to investigate the hypothesis that postulates the similarity in composition of symbiotic communities associated with morphologically similar hosts.

More specifically, in this paper we analyse: 1) The morphological and ecological characteristics of the two Vietnamese host species of Chaetopterus; 2) The composition, species richness and abundance of the symbiotic communities associated with the two host species; and 3) The host specificity of all symbiotic species. 


\section{2.- Material and methods}

Sampling was conducted between March and April 2016 in four localities of Nhatrang Bay (Vietnam, South China Sea): the western coast of Mun Island, the southern coast of Mot Island, the western coast of Tre Island and Dam Bay (Fig. 1, Table 1). A copy of the letter from the Russian-Vietnamese Tropical Center supporting the collection of samples and animals used in this paper has been provided to PeerJ as a supplementary file.

The chaetopterid hosts were collected by SCUBA diving at depths from 6 to $20 \mathrm{~m}$. As their tubes were embedded within the sediment to $15-20 \mathrm{~cm}$ depth, extraction was achieved by washing out the sediments by hand. The tubes were then gently removed, immediately placed into individual zip-lock plastic bags to avoid losing symbionts and transferred to seawater tanks, where they were kept until reaching the laboratory facilities.

The density of the studied population of Chaetopterus was estimated along five $50 \mathrm{~m}$ long and $2 \mathrm{~m}$ wide transects at Mun Island and Dam Bay. At each site, the transects followed the depth profile and were placed parallel, each one immediately adjacent to the previous one. Two divers were responsible for counting the number of chaetopterid tube syphons, each one on one side (1 $\mathrm{m})$ of the transect. A second density estimate was based on the number of chaetopterids sampled per hour at each sampling site (except when diving surveys were used for transect estimates).

In the laboratory, tube length was measured to the nearest $5.0 \mathrm{~mm}$ (Table S1). Then, tubes were gently opened by hand and carefully checked for presence of symbionts. The species and number of symbionts were recorded (Table S1). Water and sediment from the bag were sieved through a $1 \mathrm{~mm}$ mesh and the retained sediments were carefully inspected by eye. The body in Chaetopterus is divided into three differentiated regions: the nine-to-ten anterior-most segments, the two-to-three mid-body segments, and an undefined (but usually very numerous) number of posterior segments, which form the regions A, B, and C, respectively (Britayev \& Martin 2016). Hosts were extracted and measured either as length and width for region $A(n=8)$ or as displaced water volume in a graduate vessel to the nearest $1 \mathrm{ml}$ (all remaining specimens) (Table S1). As body volume showed a positive linear relationship with tube length (Tube length = $44.084+0.503 *$ Body volume, $\mathrm{F}=26.457, P<0.0001$; Table $\mathrm{S} 2$ ), this easy-to-obtain measurement was used to study community structure. 
120 All chaetopterid tubes, hosts and symbionts were photographed with Canon digital cameras

121 (G16 and EOS 6D). Selected hosts and all symbionts were fixed either in 70\% or 99\% ethanol, or

122 in a $4 \%$ formaldehyde/seawater solution for further studies. Small fragments of the ventral

123 uncinal tori of both host species have been dissected. To illustrate the shape of the uncini, these

124 fragments were squashed between slides, mounted in glycerine and photographed with the help

125 of a ProgRes C10 Plus digital camera (Jenoptics, Jena) attached to a Zeiss Axioplan compound 126 microscope.

127 All symbionts were measured to the nearest $0.1 \mathrm{~mm}$, using a calibrated ocular micrometer 128 under an Olympus SZX9 stereomicroscope as body length from tip of prostomium to the end of 129 pygidium for polychaetes, as body length from tip of head to the end of caudal peduncle for fish, 130 and as carapace width for crabs. Crabs were sexed according to the abdominal shape.

131 DNA was extracted using Spin Columns Thermo Scientific GeneJET 50 kit, following the 132 manufacturer's standard protocol. $10 \mathrm{ng}$ of genomic DNA was used as a template for polymerase 133 chain reaction (PCR) with special mitochondrial Cox1 primers:

134 TGTAAAACGACGGCCAGTGAYTATWTTCAACAAATCATAAAGATATTGG and 135 CAGGAAACAGCTATGACTAMACTTCWGGGTGACCAAARAATCA (Carr et al. 2011). PCR 136 were set up in total volume of $20 \mu \mathrm{l}$. The PCR cycling profiles were as follows: initial 137 denaturation $\left(95^{\circ} \mathrm{C}, 5 \mathrm{~min}\right)$; followed by 35 cycles of denaturation $\left(95^{\circ} \mathrm{C}, 15 \mathrm{sec}\right)$, annealing $138\left(45^{\circ} \mathrm{C}, 15 \mathrm{sec}\right)$ and extension $\left(72^{\circ} \mathrm{C}, 60 \mathrm{sec}\right)$. The resulting PCR products were purified by direct 139 purification from the PCR mixture and prepared for sequencing. Overlapping sequence 140 fragments were merged into consensus sequences using MEGA7 (Kumar et al. 2016), the protein 141 coding COI being simple to align. The obtained COI sequences and voucher paragenophores 142 (Pleijel et al. 2008) for the two species of Chaetopterus have been deposited in GenBank and in 143 the collections of the Severtsov Institute of Ecology and Evolution RAS, respectively. Seven host 144 specimens were used in genetic analyses to ensure species delineation (Table 2). The genetic 145 differentiation within and between species was assessed by pairwise genetic distances between 146 COI sequences using the Maximum Likelihood Model, which allowed us to show the percentage 147 of replicate trees in which the associated taxa clustered together in the bootstrap test (1000 148 replicates) next to each branch (Felsenstein 1985). The phylogenetic tree was drawn to scale, 149 with branch lengths in the same units as those of the evolutionary distances used to infer it, as 150 computed using the Maximum Composite Likelihood method (Tamura et al. 2004) and are in the 151 units of the number of base substitutions per site. The phylogenetic tree was built using the COI 152 sequences of Chaetopterus and Mesochaetopterus available from NCBI GenBank, using 
153 Spiocharopterus costarum (Claparède 1869) as the outgroup, by means of the Neighbor-Joining 154 method (Saitou \& Nei 1987) in MEGA7 (Kumar et al. 2016).

155 For the purposes of our study, the following terms are defined: Prevalence, as the ratio 156 between number of infested and total number of hosts; Intensity, as the number of symbionts 157 present in each infested host; Mean intensity, as the mean number of individuals of a particular 158 symbiotic species per infested host in a sample; Abundance, as mean number of symbionts per 159 examined host, infested and non-infested; and Species richness, as mean number of symbiotic 160 species per infested host.

161 The porcellanid crabs were identified by Prof. Bernd Werding, from the Institut für 162 Allgemenie und Spezielle Zoologie of the Justus-Liebig Universität (Giessen, Germany). The 163 pinnotherid crab was identified by Prof. Peter Ng from the Department of Zoology of the 164 National University of Singapore (Republic of Singapore). The carapid fish was identified by Dr. 165 Eric Parmentier from the Laboratoire de Morphologie Fonctionnelle et Evolutive of the Institut 166 de Chimie of the Université de Liege (Belgium). The tergipedid nudibranch was identified by Dr. 167 Irina Ekimova, from the Department of Invertebrate Zoology of the Lomonosov Moscow State 168 University (Russian Federation).

169 The relationship between host body volume and tube length were assessed by linear 170 regression. The species richness and mean intensity, as well as the average length of infested and 171 non-infested tubes of Chaetopterus, were compared by Student's t-test. Statistical analyses were 172 performed using Statistica 6.0 and PAST 2.17 software.

\section{3.- Results}

\section{3.1.- Hosts characteristics}

175 The two Vietnamese host species of Chaetopterus are morphologically similar. However, 176 one of them is significantly bigger than the other, both in terms of tube length (1.4:1, on average) 177 and body volume (2.7:1, on average) (t-test $\mathrm{p}<0.0001$, Table 3$)$. They also differ in the number of 178 chaetigers of region A (9 and 9-11, respectively) (Fig. 2A, 2D) and in the denticles of the 179 neuropodial uncini of region $\mathrm{C}$ (25-35 and 9, respectively) (Fig. 3A-D), as well as in tube 180 structure. Tubes of the bigger species are covered by silt, have a parchment-like appearance and 181 the inner lining is iridescent, silver or golden in colour, showing distinct transverse annulations 182 (Fig. 2C). In the smaller species, tubes are covered by sand and small coral and shell fragments, 
183 have a paper-like appearance with a semi-transparent inner lining, whitish or brownish in colour 184 and lacking distinct annulations (Fig. 2F).

185 We tentatively identified the bigger host species as Chaetopterus cf. appendiculatus 186 because, according to the original description, this species has a sand-coloured inner tube surface, 187 showing dense transverse annulations. Additionally, it is the only described species of 188 Chaetopterus possessing neuropodial uncini from region $\mathrm{C}$ with more than 20 small denticles. 189 Chaetopterus appendiculatus was already reported as host of $O$. pettiboneae from the Banda Sea 190 (Indonesia) by Petersen \& Britayev (1997). Petersen (1997) proposed the redescription of $C$. 191 appendiculatus as a valid species, based on the type material from Ceylon. The fact that formal 192 redescription has never been published does not prevent us from considering the species as valid, 193 whose formal redescription is far beyond the scope of this paper. However, the long geographical 194 distance between Ceylon/Indonesia and Vietnam prevents us in fully assigning the Vietnamese 195 specimens to $C$. appendiculatus, and we refer to the species as $C$. cf. appendiculatus in this paper. 196 The smaller host is likely undescribed.

197 The phylogenetic analysis including the COI sequences of the Vietnamese hosts (Fig. 4) 198 showed low bootstrap values that did not allow us to fully resolve the phylogeny of 199 Chaetopterus. However, it clearly revealed that the two Vietnamese hosts are different species 200 included within two separate monophyletic clades (with 100\% bootstrap support), thus 201 confirming our morphological inference. Although with low support, the closest clades to those 202 of the two Vietnamese Chaetopterus belong to C. variopedatus (Renier 1804). However, the 203 specimens joining the Chaetopterus sp. clade (42\% bootstrap support) originate from the 204 Mediterranean, while those joining the $C$. cf. appendiculatus clade (54\% bootstrap support) 205 originate from the Atlantic. As indicated by Martin et al. (2008), our results support the inference 206 that the two populations of $C$. variopedatus belong to different species, with the Mediterranean 207 species described and the Atlantic species still undescribed. The results also confirm that $C$. 208 variopedatus sensu Hartman (1959) is not a single cosmopolitan species, but a complex including 209 more than 20 different species (Bhaud 1998; Osborn et al. 2007; Petersen 1984a; Petersen 1984b; 210 Petersen 1997). As is the case for C. appendiculatus, some of these species have not yet been 211 formally redescribed. However, as many as nine species have recently been described, and five 212 have been redescribed in the recent literature (Nishi 2001; Nishi et al. 2000; Nishi et al. 2009; 213 Osborn et al. 2007; Sun \& Qiu 2014).

214 The two Vietnamese Chaetopterus host species were found at the same localities, with their 215 tubes deeply embedded in silty sand sediments. Chaetopterus cf. appendiculatus outnumbered 
216 Chaetopterus sp. in all samples, yet their proportion varied depending on the locality, with

217 Chaetopterus sp. being relatively more abundant at Mot Islands (St. 2, 25.9\%) and substantially

218 less abundant at the other stations (5.0-9.1\%) (Table 1).

219 The density of Chaetopterus ranged from 0.6 to 1.0 individuals per $100 \mathrm{~m}^{2}$ in the transects,

220 while the number of collected worms per diving hour was lower at St. 4 in Dam Bay and higher

221 at St. 1 in Point Nam, Tre Island (Table 1).

222 3.2.- Taxonomic composition of the symbiotic communities

22391 individuals of seven species of animals occurred in association with the two host species

224 of Chaetopterus. Among them, the polynoid polychaete Ophthalmonoe pettiboneae (Fig. 5C), the

225 tergipedid nudibranch Phestilla sp. (Fig. 6G), the carapid fish Onuxodon fowleri (Smith 1964)

226 (Fig. 5D), and four species of decapods, three porcellanids, Eulenaios cometes (Walker 1887)

227 (Fig. 5A, 5B), Polyonyx cf. heox Osawa \& Ng, 2016 (Fig. 6A, 6B) and Polyonyx sp. (Fig. 6E,

228 6F), and the pinnotherid Tetrias sp. (Fig. 6C, 6D) (Table 4).

229 Four and three species were found inside the tubes of Chaetopterus sp. and C. cf.

230 appendiculatus, respectively. Surprisingly, the symbiotic communities associated with the two

231 hosts did not have any species in common, with the only similarity at a higher taxonomic level

232 being the presence of porcellanid crabs (Table 4). Despite the lower sample size of Chaetopterus

233 sp., the diversity of its associated community was higher than that of $C$. cf. appendiculatus.

234 Accordingly, it may be expected that the number of species associated with Chaetopterus sp.

235 would increase with an increasing number of analysed host individuals. Conversely, the diversity

236 of the community associated with $C$. cf. appendiculatus showed an almost saturated species

237 accumulation curve (Fig. 7A).

238 Ophthlmonoe pettiboneae is the single symbiotic species previously known from

239 Vietnamese waters and from the same host species. The other six are here reported for the first

240 time from the Vietnamese coasts. Moreover, O. fowleri is herein reported as a symbiont of

241 chaetopterids for the first time, as well as Tetrias sp., Polyonyx sp., P. cf. heox and Phestilla sp.,

242 which are new to science and will be described at later dates in specialized papers. The tergipedid

243 nudibranch is also, to the best of our knowledge, the first known nudibranch living in symbiosis

244 with a polychaete host. It shows a posterior end functioning as a sucker (Fig. 6F) allowing it to

245 attach to the smooth inner surface of the host tube, while the rest of the body can move freely

246 (https://www.researchgate.net/publication/310159685_Phestilla_sp). Its flattened body, together

247 with the lack of cnidosacs and the uniserial radula with long lateral denticles on the rachidian 
248 tooth clearly place it within the genus Phestilla. However, it differs from all known species of

249 this genus by having a small central denticle of the radula, a wider foot and cerata arranged one

250 per row only (Deart and Ekimova, personal communication). Moreover, its appearance and

251 colouring (Fig. 6F) mimics, to some extent, that of the very posterior end of the chaetopterid host.

252 3.3.- Structure of the symbiotic communities

253

$56(69.5 \%)$ out of 83 individuals of C. appediculatus and all 11 (100\%) Chaetopterus sp.

254 were infested. Among the species associated with C. appediculatus, O. pettiboneae showed a

255 higher prevalence than the two other symbionts (Table 4). Among the associates with

256 Chaetopterus sp., the prevalence ranged from $11 \%$ to almost $90 \%$, with the maximum

257 corresponding to $P$. cf. heox (Table 4).

258 The number of species inhabiting the same tube varied from 0 to 2 in $C$. cf. appendiculatus,

259 and from 1 to 2 in Chaetopterus sp. However, the species richness was significantly higher in the

260 latter ( $p>0.001$, Fig. 7A, 7B) due to the common coexistence of two symbiont species in the same

261 host tube. In fact, the small-sized Polyonyx sp. and Phestilla sp. (Fig. 6E-6G) were found in all

262 observed cases living with other crab species, mostly with the large sized P. cf. heox (Fig. 6A,

263 6B). Only in one case, Polyonyx sp. shared the host tube with Tetrias sp. (Table 6). In contrast,

264 most tubes of $C$. appediculatus were occupied by a single symbiotic species, either $O$.

265 pettiboneae or $O$. fowleri. Only in one case two species of symbionts (O. pettiboneae and E.

266 cometes) were present sharing the same host tube (Table 6).

267 The number of symbiont individuals infesting one host varied from 0 to 3 in $C$. cf.

268 appediculatus, and from 1 to 5 in Chaetopterus sp., while the mean intensity was nearly three

269 times lower in the former than in the later ( $>0.001$, Table 5). Accordingly, most $C$. cf.

270 appediculatus were infested by one symbiotic individual, while multiple infestation (two, three,

271 or even four symbionts) was common in Chaetopterus sp. (Fig. 7B).

272 The distribution pattern of the symbionts among their hosts was primarily regular, as all. $O$.

273 pettiboneae and most O. fowleri lived solitary inside their host tubes. In turn, Polyonyx cf. heox,

274 Polyonyx sp., E. cometes, Tetrias sp. were found in host tubes usually as male/female pair. The

275 number of nudibranchs varied from 1 to 3 per hosts (Table 6) and, in one case, a couple was

276 observed near to a recently spawned egg-mass attached to the inner side of the host tube (Fig.

$2776 \mathrm{H})$.

278 The component communities differed also in the relative abundance of a particular species.

279 In the community associated with $C$. cf. appendiculatus, O. pettiboneae was dominant in terms of 
280 both prevalence and abundance. In the community associated with Chaetopterus sp., the 281 dominance of the most abundant symbiont, $P$. cf. heox is less distinctive, with the role that other 282 species had in the community structure being more relevant (Fig. 7C).

283 The average length of infested and non-infested tubes of C. appediculatus does not differ 284 significantly $(41.2-42.3$, t-test, $\mathrm{p}=0.65)$. The number of both symbiotic species and individuals do 285 not show any significant correlation with host tube length in both chaetopterid species.

\section{4.- Discussion}

\section{1.- Community dissimilarity}

Our results demonstrate a strict segregation in species composition of the communities associated with the two Vietnamese syntopic species of Chaetopterus, which had no species in common. However, at higher taxonomic levels (i.e., family, order and class), they were similar to each other and also resembled the symbiotic communities associated with other species of Chaetopterus and, even, echiuran worms in harbouring scale-worms, pocellanid and pinnotherid decapods and fishes (Anker et al. 2005; Gray 1961; Ng \& Sasekumar 1993; Petersen \& Britayev 1997).

The two Vietnamese species of Chaetopterus are very similar in body morphology and tube shape, as well as in their trophic-functional characteristics. Thus, no reasons linked to host morphology were evident allowing us to explain the dissimilarity in symbiotic species composition. We suggest therefore that community composition appears to be determined by historical events rather than by the physical or biological habitat characteristics. We may hypothesize that both host species were originally allopatric. Thus, the evolutionary establishment of the respective specialized symbiotic associations would likely occur in different, separated geographical areas, with the posterior disappearance of geographical barriers leading to the current overlapping distribution. Once established, the respective symbiotic communities would be maintained by interspecific competition, leading to symbiont specialization to their respective host species as well as to preventing the exchange of symbionts between hosts when becoming sympatric, even being as closely related as is the case for these two species of Chaetopterus. However, our hypothesis does not exclude the possible existence of differences in host physiology or behaviour that would enhance the ability of the specialized symbionts to 
309 compete with possible invaders, thus contributing to maintain the differences in community 310 composition.

311 Further assessment of this hypothesis would require an experimental approach to analyse 312 the possible existence of a host-factor allowing the respective symbiont to recognize their own 313 hosts, as well as to check the ability of the symbionts from one host to infest the other. In parallel,

314 the regularity of the community segregation would have to be checked by more extensive field 315 sampling addressed to discard (or reveal) the presence of additional symbionts on the alternative 316 host species. This is particularly relevant for Chaetopterus sp. whose accumulation curve (Fig. 317 7A) supports an expected increase in the respective number of symbiotic species with sampling 318 size. An additional, but not less pertinent question would be to assess the degree of specialization 319 of the symbionts found in the two species of Chaetopterus, either based on previously published 320 data or on our own observations. Therefore, it would be particularly relevant to consider whether 321 they are obligatory or facultative and, in the case of obligatory symbionts, to further assess their 322 degree of specificity (which may range from species-specific to opportunistic).

324 Among the seven species of macroinvertebrates associated with $C$. cf. appendiculatus and 325 Chaetopterus sp., four (i.e., one polychaete $O$. pettiboneae, one crab, E. cometes, and one fish, $O$. 326 fowleri) are known as obligatory symbionts of chaetopterids and other benthic organisms. 327 Onuxodorn fowleri also lives in the mantle cavity of bivalves and inside holothurians (Markle \& 328 Olney 1990; Parmentier et al. 2002). In our samples, five of six individuals were juveniles, which 329 allows us to suggest that they are employing $C$. cf. appendiculatus as temporal or intermediate 330 hosts. The porcellanid E. cometes was reported from shallow waters off Singapore, living in 331 association with a species of Chaetopterus, identified as C. variopedatus but this identification is 332 undoubtedly incorrect $(\mathrm{Ng} \&$ Nakasone 1993). In turn, the scale-worm O. pettiboneae was first 333 reported from Ambon Island (Indonesia) and later from the coasts of Vietnam, always in 334 association with C. cf. appendiculatus (Britayev \& Martin 2005; Petersen \& Britayev 1997; this 335 paper).

336 The four other species appear to be undescribed and are now being analyzed by the 337 corresponding specialists. However, we may infer some considerations on their degree of 338 specialization based on existing papers dealing with the ecology and morphology of some closely 339 related taxa. Concerning the symbiotic crabs, the porcellanid Polyonyx sp. belongs to the 340 "Polyonyx sinensis" species complex, usually obligatory associates of tubicolous polychaetes, 
341 mainly with species of Chaetopterus (B. Werding, unpublished data), while Polyonyx cf. heox

342 belongs to the "Polyonyx pedalis" complex and the same or a very similar species has been

343 recently reported from Singapore living in association with Chaetopterus cf. pacificus (Osawa \&

$344 \mathrm{Ng}$ 2016). This suggests that both porcellanids are obligate and, probably, specialized symbionts

345 of Chaetopterus sp. In turn, Tetrias sp. belongs to the Pinnotheridae, a family that mainly

346 includes symbiotic species living as endo- or ectosymbionts in mollusc mantle cavities,

347 polychaete burrows, echinoid integuments or tunicate branchial sacs (Drake et al. 2014). Among

348 them, two species of Tetrias are currently known. Tetrias fischerii (Milne-Edwards 1867) has

349 been reported as symbiont of bivalves and annelids, while the host of Tetrias scabripes Rathbun,

3501898 is unknown (Schmitt et al. 1973). Although this cannot be assessed from our data, we

351 suggest that the species associated with the Vietnamese Chaetopterus sp. is a specialized 352 obligatory symbiont.

353 The third undescribed species, the nudibranch Phestilla sp., has several behavioural (i.e.,

354 two or more individuals sharing the same host, egg-masses attached to the inner tube surface) and

355 morphological (i.e., posterior end working as a sucker, overall body shape mimicking that of the

356 host) features clearly pointing toward a specialized symbiotic mode of life. This lead us to

357 consider the species as the first know nudibranch living as a symbiont with a marine annelid host.

358 Nudibranchs are well known as aposematic or mimetic organisms (Edmunds 1987; Gosliner \&

359 Behrens 1989; Rudman 1991), some of them being considered as true symbionts. Among them,

360 there are some species of Phestilla, which lives in association with corals and are highly

361 specialized predators (Faucci et al. 2007; Robertson 1970), while the exact nature of the

362 association of the Vietnamese Phestilla sp. and Chaetopterus sp. would need further research to

363 be defined. The single related association occurred between the goniodorid nudibranch

364 Lophodoris scala Er. Marcus \& Ev. Marcus, 1970 and the innkeeper echiurid Lissomyema exilii

365 (Müller 1883). In this case, the nudibranch lives inside the host burrow, sometimes creeping

366 along the host trunk and feeding, possibly exclusively, on Loxosomella spp., an entoproct that

367 colonizes the burrow walls (Ditadi 1982; Marcus \& Marcus 1970), which seems not to be the

368 case for the Vietnamese species.

369 Accordingly, all symbionts found in association with Chaetopterus sp. and C. cf.

370 appendiculatus have to be considered as obligatory symbionts. Among them, the less specialized

371 is $O$. fowleri, which is known to infest hosts belonging to different types of animals (molluscs

372 and polychaetes). The porcellanid crabs $E$. cometes and $P$. cf. heok are probably genus-specific

373 symbionts, while the scale-worm O. pettiboneae, together with the other porcellanid crab 
374 Polyonyx sp. and the tergipedid nudibranch Phestilla sp., must be considered as species-specific

375 symbionts. The specificity of the pinnotherid crab Tetrias sp. is not clear at this time. However,

376 taking into account the relative abundance of pinnotherids among symbionts of Chaetopterus

377 species (Petersen \& Britayev 1997; Schmitt et al. 1973), we could also propose that it should be

378 considered as a specialized symbiont, at least at family level.

379 Therefore, we consider all symbionts found in association with the two Vietnamese species

380 of Chaetopterus as being, or tending to be, specialized symbionts, the single exception being the 381 carapid fish.

4.3.- Possible causes of observed differences in community structure

383 We found substantial differences in the structure of the symbiotic communities associated

384 with Chaetopterus sp. and C. cf. appendiculatus. The first shows a significantly higher species

385 richness and mean abundance than the second, while the second was clearly dominated by the

386 presence of a single species, both in terms of abundance and frequency (Table 5, Fig. 6C). Taking

387 into account that body size and tube length of Chaetopterus sp. are significantly lower than those

388 of $C$. cf. appendiculatus, this situation is particularly unexpected. Usually, species richness and

389 abundance increase with the increasing host size (e.g., Abele \& Patton 1976; Ribeiro et al. 2003).

390 Thus, the sitiuation of the Vietnamese partnership requires specific considerations.

391 We suggest that several factors are shaping the differences in the structure of the

392 symbiotic communities associated with Chaetopterus sp. and C. cf. appendiculatus. Despite both

393 host species having low population densities in Nhatrang Bay, that of Chaetopterus sp. was

394 significantly lower, which would likely force the associated symbionts to use (and share) the few

395 available hosts. This would possible explain the higher number of species in its associated

396 community, as well as the fact that all host individuals of Chaetopterus sp. found in Nhatrang

397 Bay harboured symbionts, in contrast to $C$. appenciculatus whose maximum prevalence was

398 around $70 \%$. Alternatively, the low density of both host populations may impede the secondary

399 dispersion of the symbionts, which has been considered as a key mechanisms shaping the

400 establishment and functioning of marine symbiotic communities (Mekhova et al. 2015) and raises

401 the question on the adults' ability of long-distance migration.

402 Based on species and individual's distributions among hosts, we also hypothesized that

403 another factor determining the observed differences in symbiotic community structure could be

404 the existence of inter- and intraspecific competition. In fact, most tubes of Chaetopterus sp. were

405 occupied by a minimum of two symbiotic species, this co-occurence being very rare in $C$. cf. 
406 appendiculatus, where each host individual was infested by one symbiotic species (Fig. 7B). The

407 single exception was a host tube shared by $O$. pettiboneae and E. cometes. Accordingly, we 408 suggest that the main driving factors may be resource partitioning between symbiotic species 409 having different sizes, in the case of Chaetopterus sp., and strong interspecific interactions, in the 410 case of $C$. cf. appendiculatus as previously reported for holothurian hosts (Lyskin \& Britayev 411 2005).

412 The characteristics of the symbiotic community structure associated with $C$. cf. 413 appendiculatus, in which one host was usually occupied by one symbiotic species (Table 6), 414 suggest the existence of interspecific competition between the polychaete and fish symbionts. In 415 turn, the fact that there was a single symbiont per host (Table 6) supports the existence of 416 intraspecific competition among polychaetes and fish individuals, respectively. At least for the 417 polychaete, this hypothesis was supported by our direct observations in experimental aquaria, 418 where individuals of $O$. pettiboneae where found to fight when trying to occupy the same host 419 tube, as well as by the high frequency of body traumas present (Britayev and Martin, unpublished 420 data). In contrast, the bulk of Chaetopterus sp. symbionts were crabs (Fig. 7C). Territorial 421 defence is a well-known phenomenon in symbiotic decapods too (Baeza et al. 2002; Huber 1987; 422 Vannini 1985). However, their behaviour has a sexual component, as they often form 423 heterosexual pairs consisting of gravid males and females co-inhabiting the same host (Castro 424 2015; Patton 1994), which was exactly the case of most porcellanid and pinnotherid crabs 425 inhabiting the tubes of the two Vietnamese species of Chaetopterus (Table 6). This behaviour 426 lead to a significant increase in the abundance of symbiotic individuals in the community 427 associated with Chaetopterus sp. Therefore, while interspecific interactions seemed to affect both 428 species richness and abundance, the intraspecific ones only affected the abundance.

429 Our observations support two main factors determining the structure of symbiotic 430 communities associated with Chaetopterus sp. and C. cf. appendiculatus in Nhatrang Bay: the 431 density of host populations and competition (both inter- and intraspecific). Moreover, the 432 observed differences in community structure appear to be strictly related to the respective species 433 composition. Accordingly, living in pairs and resource partitioning led to species coexisting in the 434 tubes of Chaetopterus sp. and establish a tightly packed component community showing high 435 species richness and mean intensity, together with a low species dominance. In contrast, the 436 aggressive, strictly territorial species associated with $C$. cf. appendiculatus established a 437 component community strongly dominated by host being inhabited by a single species and, thus, 438 low species richness and mean intensity. 
439 The existence of two closely related host species with overlapping distributions but

440 harbouring very different symbiotic communities seems to be unusual. We suggest that it may

441 probably be related with the scarcity of data currently available on the structure of symbiotic

442 communities in marine environments. However, the situation is certainly not unique, as at least

443 an additional example has been recently reported from Nhatrang Bay. In this case, the hosts were

444 comatulid crinoids Comanthus gisleni Rowe, Hoggett, Birtles \& Vail, 1986 and C. parvicirrus

445 (Müller, 1841) (Mekhova \& Britayev 2012). Consequently, we expect further worldwide studies

446 to discover more syntopic hosts harbouring symbiotic communities with contrasted composition

447 and structure.

\section{5.- Conclusions}

Two symbiotic communities inhabit the morphologically similar and syntopic species of the tube-dwelling chaetopterid polychaetes Chaetopterus sp. and C. cf. appendiculatus in Nhatrang Bay. They are mostly composed of specifically specialized species and show a very different composition. The current situation has been attributed to an initially allopatric host distribution allowing the symbiotic communities to be established independently. This is then followed by the subsequent disappearance of the original geographical barriers leading to the current sympatry. The present symbiotic communities differ in structural characteristics (i.e., species richness, mean intensity and species dominance) as a consequence of the differences in host density but also of the existing intra- and interspecific interactions that, in turn, depends on the behaviour of the respective symbiotic species. Mating pairs and partitioned resources lead to a high diversity and intensity in the community associated with Chaetopterus sp., while the aggressive and territorial species associated with $C$. cf. appendiculatus led to a community with low diversity and intensity but with a strong dominance of a single species.

The hypotheses postulating a similar composition for the symbiotic communities established on closely related hosts seems to reflect a rather common situation in marine ecosystems and, certainly, our results do not allow us to reject it. In fact, the opposite situation was observed within our data, with two taxonomically related hosts living in the same habitat that harbour symbiotic communities with contrasted species composition. Therefore, we hypothesize on the possible reasons explaining their establishment. We also highlight that the situation of the

468 Vietnamese partnerships is certainly not unique and should be considered as an interesting model 
469 to further assess different evolutionary and ecological aspects of the establishment of a symbiotic 470 community.

471 Our results also highlight the importance of studying previously unknown symbiotic 472 associations, which may provide key information allowing the complex network of relationships 473 driving the functioning of the marine ecosystems, particularly in benthic environments, to be 474 understood. Moreover, they are crucial in revealing the hidden biodiversity of the oceans, as 475 supported by the fact that at least five of the nine species herein studied are currently 476 undescribed.

\section{Acknowledgements}

We would like to thank our colleagues from the Coastal Branch of the Russian-Vietnamese Tropical Centre, Mrs Hai Thanh Nguyen, Mr Tchan Than Kuang and Mr N.L. Filichev for their help in conducting field and experimental studies, Dr V.N. Mikheev for fruitful discussion and constructive advices in preparing the manuscript, Dr K. Mortimer-Jones for kindly checking the English style of the last version of the manuscript and Dr X. Turon for suggesting improvements on the interpretation of the phylogenetic tree. We would also like to thank Professors B. Werding and P. Ng Kee Lin, and Drs. E. Permentier and Irina Ekimova for kindly identifying the 485 porcellanid, pinnotherid, carapid and nudibranch symbionts.

\section{References}

Abele LG, and Patton WK. 1976. The size of coral heads and the community biology of associated decapod crustaceans. Journal of Biogeography 3:35-47. 10.2307/3038097

Anker A, Murina GV, Lira C, Vera Caripe JA, Palmer AR, and Jeng MS. 2005. Macrofauna associated with echiuran burrows: A review with new observations of the innkeeper worm, Ochetostoma erythrogrammon Leuckart and Rüppel, in Venezuela. Zoological Studies 44:157-190. 10.1007/s12630-011-9640-1

Antokhina TI, Savinkin OV, and Britayev TA. 2012. Asteroidea of Vietnam with some notes on their symbionts. Benthic fauna of the Bay of Nhatrang, Southern Vietnam Vol 2 Moscow: KMK Scien:428. 
496 Baeza J, Stotz W, and Thiel M. 2002. Agonistic behaviour and development of territoriality 497 during ontogeny of the sea anemone dwelling crab Allopetrolisthes spinifrons (H. Milne Edwards, 1837)(Decapoda: Anomura: Porcellanidae). Marine and Freshwater Behaviour and Physiology 35:189-202. 10.1080/1023624021000003817

Baeza JA. 2015. Crustaceans as symbionts: An overview of their diversity, host use, and lifestyles. In: Thiel M, and Watling L, eds. Lifestyles and Feeding Biology. New York: Oxford University Press, 163-189.

Barel CDN, and Kramers PGN. 1977. A survey of the echinoderm associates of the North-East Atlantic area. Zoologische Verhandelingen Leiden 156:1-159.

Bhaud M. 1998. The spreading potential of polychaete larvae does not predict adult distributions, consequences for conditions of recruitment. Hydrobiologia 375/376:35-47.

Britayev TA. 1993. Pilargis berkeleyae (Polychaeta, Pilargidae) as a commensal of a sedentary polychaete Chaetopterus cautus (Chaetopteridae). [In Russian]. Zoologicheski Zhurnal 72:147-151.

Britayev TA, and Martin D. 2005. Scale-worms (Polychaeta, Polynoidae) associated with chaetopterid worms (Polychaeta, Chaetopteridae), with description of a new genus and species. Journal of Natural History 39:4081-4099. 10.1080/00222930600556229

Britayev TA, and Martin D. 2016. Chaetopteridae Audouin \& Milne Edwards, 1833. In: Boggemann M, Westheide W, and Purschke G, eds. Handbook of Zoology Annelida. Berlin. Published ahead of print in Zoology online: De Gruyter, 1-17.

Carr CM, Hardy SM, Brown TM, Macdonald TA, and Hebert PD. 2011. A tri-oceanic perspective: DNA barcoding reveals geographic structure and cryptic diversity in Canadian polychaetes. PLOS ONE 6:e22232. 10.1371/journal.pone.0022232

Castro P. 2015. Symbiotic Brachyura. In: Castro P, Davie P, Guinot D, Schram FR, and von Vaupel Klein JC, eds. Treatise on Zoology-Anatomy, Taxonomy, Biology The Crustacea, Volume 9 Part C (2 vols): Brill, 543-581.

Claparède É. 1869. Les Annélides Chétopodes du Golfe de Naples. Seconde partie. Annélides sédentaires. Mémoires de la Société de physique et d'histoire naturelle de Genève 20:1-225.

Cuvier G. 1830. Le règne animal distribué d'après son organisation, pour servir de base a l'histoire naturelle des animaux et d'introduction a l'anatomie comparée. Paris: Déterville et Crochard.

Deheyn D, Lyskin SA, and Eeckahaut I. 2006. Assemblages of symbionts in tropical shallowwater crinoids and assessment of symbionts' host-specificity. Symbiosis 42:161-168. 
529 Ditadi ASF. 1982. On the burrows of echiuran worms (Echiura): a survey. Boletim de Zoologia 530 da Universidade de Sao Paulo 7:21-36.

531 Drake P, Marco-Herrero H, Subida MD, Arias AM, and Cuesta JA. 2014. Host use pattern of the 532 pea crab Afropinnotheres monodi: potential effects on its reproductive success and 533 geographical expansion. Marine Ecology Progress Series 498:203-215. 10.3354/meps10623

534 Duffy JE. 2002. The ecology and evolution of eusociality in sponge-dwelling shrimp. In: Kikuchi 535 T, ed. Genes, behaviors and evolution of social insects. Sapporo: Hokkaido University Press, 536 217-254.

537 Edmunds M. 1987. Color in opisthobranchs. American Malacological Bulletin 5:185-196.

538 Enders HE. 1909. A study of the life-history and habits of Chaetopterus variopedatus. Journal of 539 Morphology 20:479-531. 10.1002/jmor.1050200306

540 Faucci A, Toonen RJ, and Hadfield MG. 2007. Host shift and speciation in a coral-feeding $541 \quad$ nudibranch. Proceedings of the Royal Society of London B: Biological Sciences 274:111-119.

542 Felsenstein J. 1985. Confidence limits on phylogenies: an approach using the bootstrap. 543 Evolution:783-791.

544 Gosliner TM, and Behrens DW. 1989. Special resemblance, aposematic coloration and mimicry 545 in opisthobranch gastropods. In: Wicksten M, ed. Symposium on the Adaptive Significance of 546 Color in Invertebrates. College Station, TX: Texas A\&M University Press, 127-138.

547 Goto R, and Kato M. 2011. Geographic mosaic of mutually exclusive dominance of obligate 548 commensals in symbiotic communities associated with a burrowing echiuran worm. Marine 549 Biology 159:319-330. 10.1007/s00227-011-1810-8

550 Gray IE. 1961. Changes in abundance of the commensal crabs of Chaetopterus. The Biological 551

552 Grube AE. 1874. Descriptiones Annulatorum novorum mare Ceylonicum habitantium ab honoratissimo Holdsworth collectorum. Proceedings of the Zoological Society of London 41:325-329. 10.1111/j.1096-3642.1874.tb02492.x

Hartman O. 1959. Catalogue of the polychaetous Annelids of the World, parts 1-2. Allan Hancock Foundation Publications, Occasional Papers 23:1-628.

Hoeksema BW, Van der Meij SE, and Fransen CH. 2012. The mushroom coral as a habitat. Journal of the Marine Biological Association of the United Kingdom 92:647-663. dx.doi.org/10.1017/S0025315411001445

Huber ME. 1987. Aggressive behaviour of Trapezia intermedia Miers and T. digitalis Latreilli (Brachiura: Xantidae). Journal of Crustacean Biology 7:238-248. 
562 Kumar S, Stecher G, and Tamura K. 2016. MEGA7: Molecular Evolutionary Genetics Analysis 563 version 7.0 for bigger datasets. Molecular Biology and Evolution:msw054.

564 Lyskin SA, and Britayev TA. 2005. Symbionts of holothurians from South Vietnam: Intra- and 565 interspecific interactions. Doklady Biological Sciences 401:116-119. 10.1007/s10630-005$566 \quad 0060-7$

567 Marcus E, and Marcus EDB-R. 1970. Opisthobranchs from Curaçao and faunistically related 568 regions. Studies on the Fauna of Curaçao and other Caribbean Islands 33:1-129.

569 Marenzeller E. 1879. Südjapanische Anneliden. I. Amphinomea, Aphroditea, Lycoridea, 570 Phyllodocea, Hesionea, Syllidea, Eunicea, Glycerea, Sternaspidea, Chaetopterea, Cirratulea, 571 Amphictenea. Denkschriften der Mathematisch - Naturwissenschaftlichen Classe der 572 Kaiserlichen Akademie der Wissenschaften XLI-LX:109-154.

573 Markle DF, and Olney JE. 1990. Systematics of the pearlfishes (Pisces: Carapidae). Bulletin of $574 \quad$ Marine Science 47:269-410.

575 Martin D, Gil J, Carreras-Carbonell J, and Bhaud M. 2008. Description of a new species of 576 Mesochaetopterus (Annelida, Polychaeta, Chaetopteridae), with re-description of Mesochaetopterus xerecus and an approach to the phylogeny of the family. Zoological Journal of the Linnean Society 152:201-225.

Mekhova ES, and Britayev TA. 2012. Feather stars (Crinoidea, Comatulida) of Nhatrang Bay, Vietnam: fauna, habitat and symbionts. In: Britayev TA, and Pavlov DS, eds. Benthic fauna of the Bay of Nhatrang, Southern Vietnam. Moscow: KMK, 447-478.

Mekhova ES, Dgebuadze PY, Mikheev VN, and Britayev TA. 2015. Colonization of depopulated crinoids by symbionts: who comes from the bottom and who from the water column? Journal of the Marine Biological Association of the United Kingdom 95:1607 -1612. doi:10.1017/S0025315415000600

Milne-Edwards A. 1867. Crustacés. In: d'Orbigny AC, ed. Dictionnaire universel d'Histoire naturelle, 493-527.

Müller F. 1883. Über einiger neue Thalassema. Zeitschri für wissenscha liche Zoologie 39:334342.

$\mathrm{Ng}$ P, and Nakasone Y. 1993. Taxonomy and ecology of the porcellanid crab Polyonyx cometes Walker, 1887 (Crustacea: Decapoda), with description of a new genus. Journal of Natural History 27:1103-1117. 10.1080/00222939300770681 
593 Ng PKL, and Sasekumar A. 1993. A new species of Polyonyx Stimpson, 1858, of the P. sinensis

594 group (Crustacea: Decapoda: Anomura: Porcellanidae) commensal with a chaetopterid worm 595 from Peninsular Malaysia. Zoologische Mededelingen 67:467-472.

596 Nishi E. 2001. Partial revision of Japanese Chaetopterus (Chaetopteridae, Polychaeta), including 597 description of three new species from southern Pacific side of central Japan. Actinia Bulletin 598 599 of Manazuru Marine Laboratory for Science Education Faculty of Education and Human Sciences, Yokohama National University 14:1-26.

Nishi E, Arai H, and Sasanuma S-i. 2000. A new species of Chaetopterus (Polychaeta: Chaetopteridae) from off Tokyo Bay, Central Japan, with comments on its Bioluminescence. Actinia Bulletin of Manazuru Marine Laboratory for Science Education Faculty of Education and Human Sciences, Yokohama National University 13:1-12.

Nishi E, Hickman Jr. CP, and Bailey-Brock J. 2009. Chaetopterus and Mesochaetopterus (Polychaeta: Chaetopteridae) rom the Galapagos Islands, with descriptions of four new species. Proceedings of the Academy of Natural Sciences of Philadelphia 158:239-259. $10.1635 / 053.158 .0113$

Osawa M, and Ng PK. 2016. Revision of Polyonyx pedalis Nobili, 1906 (Crustacea: Decapoda: Anomura: Porcellanidae), with descriptions of three new species. Raffles Bulletin of Zoology, Supplement 34:499-518.

Osborn KJ, Rouse GW, Goffredi SK, and Robison BH. 2007. Description and relationships of Chaetopterus pugaporcinus, an unusual pelagic polychaete (Annelida, Chaetopteridae). Biological Bulletin Marine Biological Laboratory, Woods Hole 212:40-54.

Parmentier E, Chardon M, and Vanderwalle P. 2002. Preliminary study on the ecomorphological signification of the sound-producing complex in Carapidae. In: Aerts P, D'Août K, Herrel K, and Van Damme R, eds. Topics in Functional and Ecological Vertebrate Morphology.

Petersen ME. 1984a. Chaetopterus variopedatus (Annelida, Polychaeta): another victim of the "characteristic species" disease. American Zoologist 24:62A.

Petersen ME. 1984b. Chaetopterus variopedatus (Renier) (Annelida: Polychaeta: Chaetopteridae): a species complex. What species are being used at MBL? Biological Bulletin Marine Biological Laboratory, Woods Hole 167:513. 
626 Petersen ME. 1997. Contribution to a revision of Chaetopterus Cuvier (Polychaeta:

627 Chaetopteridae): Redescription of C. appendiculatus Grube and C. cautus Marenzeller, with 628 comments on some other species. Bulletin of Marine Science 60:619-619.

629 Petersen ME, and Britayev TA. 1997. A new genus and species of polynoid scaleworm 630 commensal with Chaetopterus appendiculatus Grube from the Banda Sea (Annelida: 631 Polychaeta), with a review of commensals of Chaetopteridae. Bulletin of Marine Science $632 \quad 60: 261-276$.

633 Pleijel F, Jondelius U, Norlinder E, Nygren A, Oxelman B, Schander C, Sundberg P, and 634 Thollesson M. 2008. Phylogenies without roots? A plea for the use of vouchers in molecular 635 phylogenetic studies. Molecular Phylogenetics and Evolution 48:369-371. http://dx.doi.org/10.1016/j.ympev.2008.03.024

Poulin R. 1998. Large-scale patterns of host use by parasites of freshwater fishes. Ecology Letters 1:118-128. 10.1046/j.1461-0248.1998.00022.x

Rathbun MJ. 1898. The Brachyura of the biological expedition to the Florida Keys and the Bahamas in 1893. Bulletin from the laboratories of natural history of the State University of Iowa 4:250-294.

Renier SA. 1804. Prospetto della Classe dei Vermi, nominati el ordinati secondo il Sistemo de Bosc. Padua.

Ribeiro SM, Omena EP, and Muricy G. 2003. Macrofauna associated to Mycale microsigmatosa (Porifera, Demospongiae) in Rio de Janeiro State, SE Brazil. Estuarine, Coastal and Shelf Science 57:951-959. 10.1016/s0272-7714(02)00425-0

Robertson R. 1970. Review of the predators and parasites of stony corals, with special reference to symbiotic prosobranch gastropods. Pacific Science 24:43-54.

Rudman WB. 1991. Purpose in pattern: the evolution of colour in chromodorid nudibranchs.

651 Saitou N, and Nei M. 1987. The neighbor-joining method: a new method for reconstructing 652 phylogenetic trees. Molecular Biology and Evolution 4:406-425.

653 Schmitt WL, McCain JC, and Davidson ES. 1973. Family Pinnotheridae. Decapoda I. Brachyura 654 I. In: Gruner H-E, and Holthuis LB, eds. Crustaceorum Catalogus. Den Haag: Dr. W. Junk 655 BV, 1-160.

656 Smith CL. 1964. Some pearlfishes from Guam, with notes on their ecology. Pacific Science 657 18:34-40. 
658 Stella J, Jones G, and Pratchett M. 2010. Variation in the structure of epifaunal invertebrate 659 assemblages among coral hosts. Coral Reefs 29:957-973. 10.1007/s00338-010-0648-8

660 Sun Y, and Qiu JW. 2014. A new species of Chaetopterus (Annelida, Chaetopteridae) from Hong $661 \quad$ Kong. Memoirs of Museum Victoria 71.

662 Tamura K, Nei M, and Kumar S. 2004. Prospects for inferring very large phylogenies by using 663 the neighbor-joining method. Proceedings of the National Academy of Sciences of the United $664 \quad$ States of America 101:11030-11035.

665 Thiel M, and Baeza JA. 2001. Factors affecting the social behaviour of crustaceans living 666 symbiotically with other marine invertebrates: a modelling approach. Symbiosis 30:163-190.

667 Vannini M. 1985. A shrimp that speaks crab-ese. Journal of Crustacean Biology 5:160-167.

668 Walker AO. 1887. Notes on a collection of Crustacea from Singapore. Journal of the Linnean 669 Society of London, Zoology 20:107-117.

670 Williams JD, and McDermott JJ. 2004. Hermit crab biocoenoses: a worldwide review of the 671 diversity and natural history of hermit crab associates. Journal of Experimental Marine 672 Biology and Ecology 305:1-128. 10.1016/j.jembe.2004.02.020 
673 Table 1. Depth (m) and geographical coordinates of the studied locations, as well as density 674 (chaetopterid individuals per $100 \mathrm{~m}^{2} /$ per diving hour), ratio of individuals (Chaetopterus sp. vs. 675 Chaetopterus cf. appendiculatus) and infestation prevalence (\%) of the respective host 676 populations; nd: no data.

\begin{tabular}{|c|c|c|c|c|c|c|c|}
\hline Locality & $\begin{array}{c}\text { Statio } \\
n\end{array}$ & Latitude & Longitude & Depth & Density & Ratio & Prevalence \\
\hline Mun Island & 1 & $12^{\circ} 10^{\prime} 10^{\prime \prime} \mathrm{N}$ & $109^{\circ} 17^{\prime} 46^{\prime \prime E}$ & $13-16$ & $1.0 / 3.8$ & $2 / 20$ & 65.2 \\
\hline Dam Bay & 2 & $12^{\circ} 11^{\prime} 43^{\prime \prime} \mathrm{N}$ & $109^{\circ} 17^{\prime} 26^{\prime \prime} \mathrm{E}$ & $6-8$ & $0.6 / 3.0$ & $2 / 23$ & 81.8 \\
\hline Mot Island & 3 & $12^{\circ} 10^{\prime} 26^{\prime \prime} \mathrm{N}$ & $109^{\circ} 16^{\prime} 23^{\prime \prime} \mathrm{E}$ & $16-20$ & $\mathrm{nd} / 4.7$ & $7 / 20$ & 90.9 \\
\hline $\begin{array}{l}\text { Point Nam } \\
\text { Tre Island }\end{array}$ & 4 & $12^{\circ} 13^{\prime} 42^{\prime \prime} \mathrm{N}$ & $109^{\circ} 13^{\prime} 47^{\prime \prime} \mathrm{E}$ & $10-12$ & $\mathrm{nd} / 7.1$ & $1 / 19$ & 60.0 \\
\hline
\end{tabular}


677 Table 2. Specimens list for the two Vietnamese host species used in the molecular analyses, 678 detailing the GenBank accession numbers and the collection references for the voucher 679 paragenophores.

\begin{tabular}{|c|c|c|c|}
\hline Chaetoperus & $\begin{array}{l}\text { Specimen } \\
\text { number }\end{array}$ & Accession number & Voucher \\
\hline cf. & & & covin DI/ln $2016 \mathrm{ch} 0001$ \\
\hline $\begin{array}{l}\text { appendiculatus } \\
\text { cf. }\end{array}$ & 14 & KY124465 & 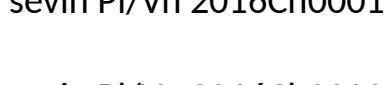 \\
\hline appendiculatus & 76 & KY124466 & sevin PI/Vn 2016Ch0002 \\
\hline appendiculatus & 77 & KY124467 & sevin $\mathrm{PI} / \mathrm{Vn} 2016 \mathrm{Ch0003}$ \\
\hline appendiculatus & 80 & KY124468 & sevin PI/Vn 2016Ch0004 \\
\hline sp. & 16 & KY124469 & sevin PI/Vn 2016Ch0005 \\
\hline sp. & 82 & KY124470 & sevin $\mathrm{PI} / \mathrm{Vn} 2016 \mathrm{Ch0006}$ \\
\hline sp. & 93 & KY124471 & sevin $\mathrm{PI} / \mathrm{Vn} 2016 \mathrm{Ch0007}$ \\
\hline
\end{tabular}


680 Table 3. Number of individuals, mean tube length ( $\min -\max$ ), $\mathrm{cm}$ and mean body volume (min 681 - max) of Chaetopterus cf. appendiculatus and Chaetopterus sp. 682

\begin{tabular}{lccc}
\hline Species & Number & Tube length $(\mathrm{cm})$ & Body volume $\left(\mathrm{cm}^{3}\right)$ \\
\hline Chaetopterus cf. appendiculatus & 83 & $64.6(41-88)$ & $41.9(23-72)$ \\
Chaetopterus sp. & 11 & $44.8(23-58)$ & $15.8(2-32)$ \\
\hline
\end{tabular}


683 Table 4. Prevalence (\%) and mean intensity (mean number of individuals per infested host) of the 684 symbiotic species associated with the two host Chaetopterus. P - Polychaeta, D - Decapoda, G 685 Gastropoda, A - Actinopteri.

\begin{tabular}{lcc}
\hline Symbiont species & Chaetopterus sp. & Chaetopterus cf. appendiculatus \\
\hline Ophthalmonoe pettiboneae (P) & - & $64.1(1.0)$ \\
Phestilla sp. (G) & $22.2(2.0)$ & - \\
Eulenaios cometes (D) & - & $1.3(2.0)$ \\
Polyonyx cf. heox (D) & $88.9(1.7)$ & - \\
Polyonyx sp. (D) & $66.7(1.3)$ & - \\
Tetrias sp. (D) & $11.1(2.0)$ & - \\
Onuxodon fowleri (A) & - & $6.4(1.2)$ \\
\hline
\end{tabular}


686 Table 5. Symbiotic community indexes: species richness (mean number of species per one 687 infested host), infestation prevalence (\%), and mean intensity (mean number of individuals per 688 infested host).

\begin{tabular}{lccc}
\hline & Richness & Prevalence & Intensity \\
\hline Chaetopterus sp. & 1.8 & 100 & 3.0 \\
Chaetopterus cf. appendiculatus & 1.02 & 67.5 & 1.05 \\
\hline
\end{tabular}


689 Table 6. Distribution among hosts (as number of host tubes found without and with 1, 2 and 3 690 individuals) for the five species associated with Chaetopterus spp. Cs: Chaetopterus sp.; Ca: 691 Chaetopterus cf. appendiculatus.

\begin{tabular}{lcccccc}
\hline Symbiont & Chaetopterus & 0 & 1 & 2 & 3 & 4 \\
\hline Ophthalmonoe pettiboneae & $\mathrm{Ca}$ & 21 & 56 & 0 & 0 & 0 \\
Onuxodon fowleri & $\mathrm{Ca}$ & 78 & 5 & 1 & 0 & 0 \\
Eulenaios cometes & $\mathrm{Ca}$ & 8 & 0 & 1 & 0 & 0 \\
Polyonyx cf. heox & $\mathrm{Cs}$ & 1 & 3 & 7 & 0 & 0 \\
Polyonyx sp. & $\mathrm{Cs}$ & 3 & 4 & 2 & 0 & 0 \\
Tetrias sp. & $\mathrm{Cs}$ & 10 & 0 & 1 & 0 & 0 \\
Phestilla sp. & $\mathrm{Cs}$ & 8 & 1 & 1 & 1 & 0 \\
\hline
\end{tabular}



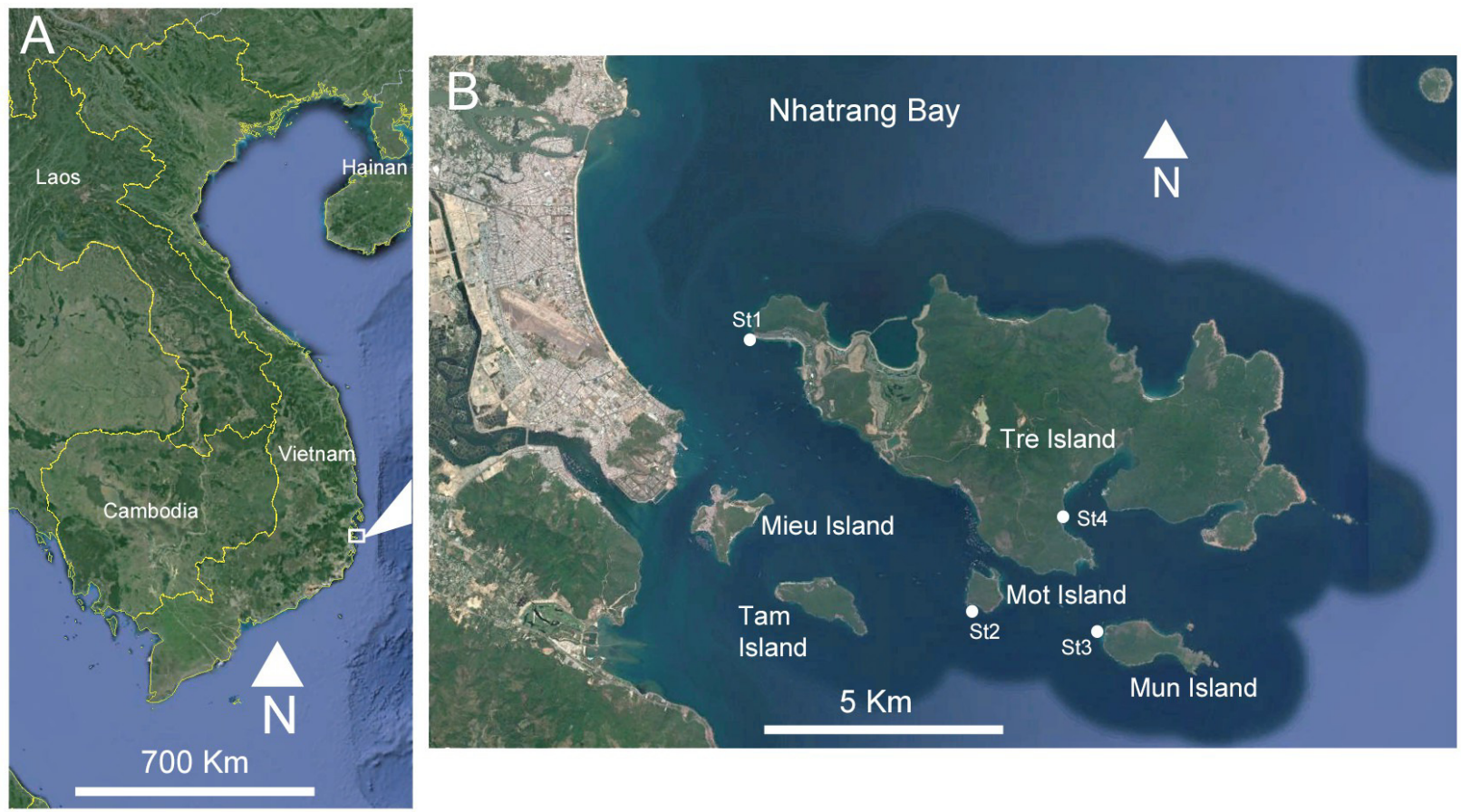

692 Figure 1. (A) Location of the study area on the Vietnamese coast of the South China Sea. (B) 693 Sampling sites, Nhatrang Bay. Map data from Google Earth Pro, (c) 2016 Google. 


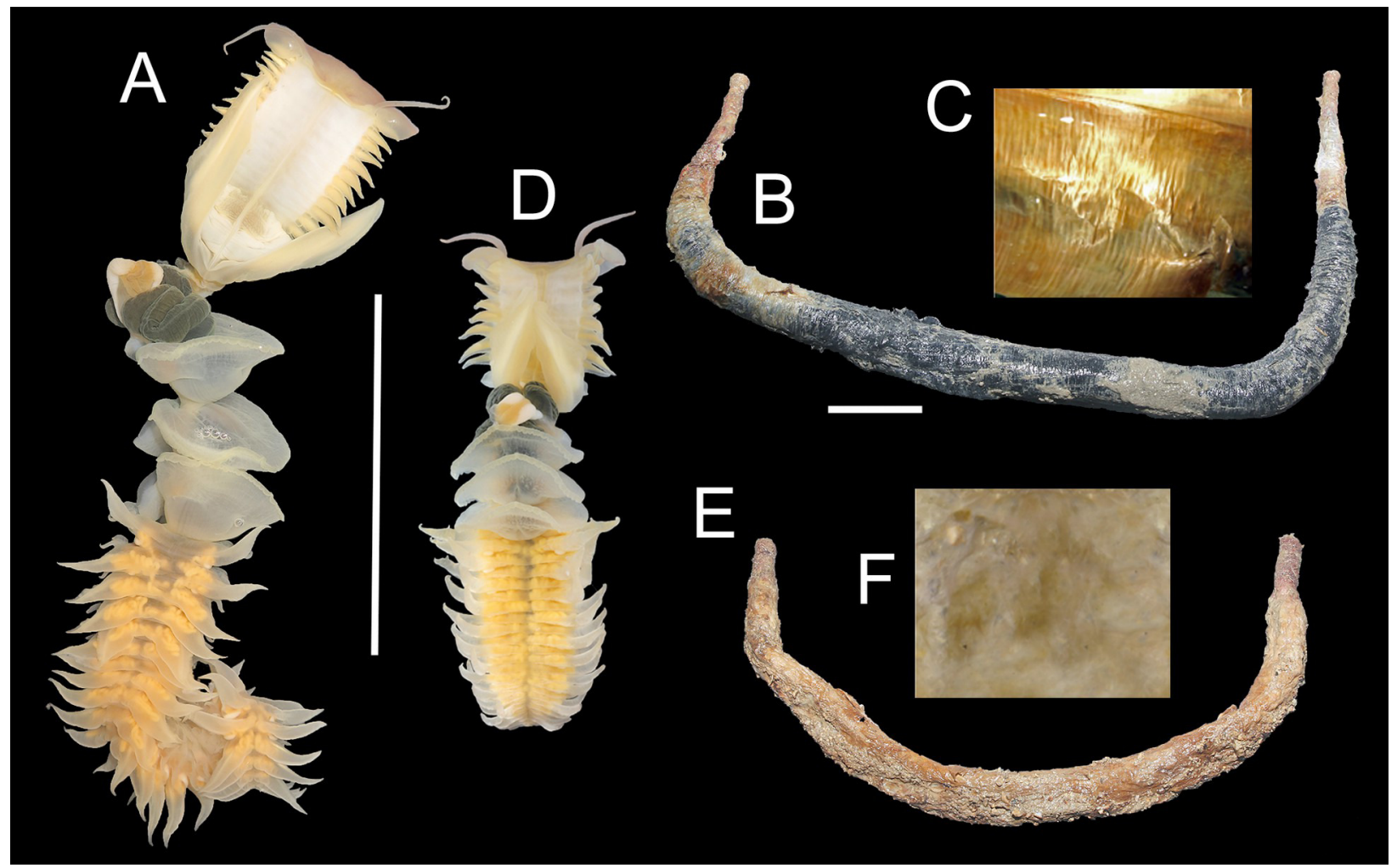

694 Figure 2. Chaetopterus cf. appendiculatus: (A) whole worm; (B) tube; (C) detail of inner tube 695 surface. Chaetopterus sp.: (D) whole worm; (E) tube; (F) detail of inner tube surface. Scale bars 696 are $5 \mathrm{~cm}$. 


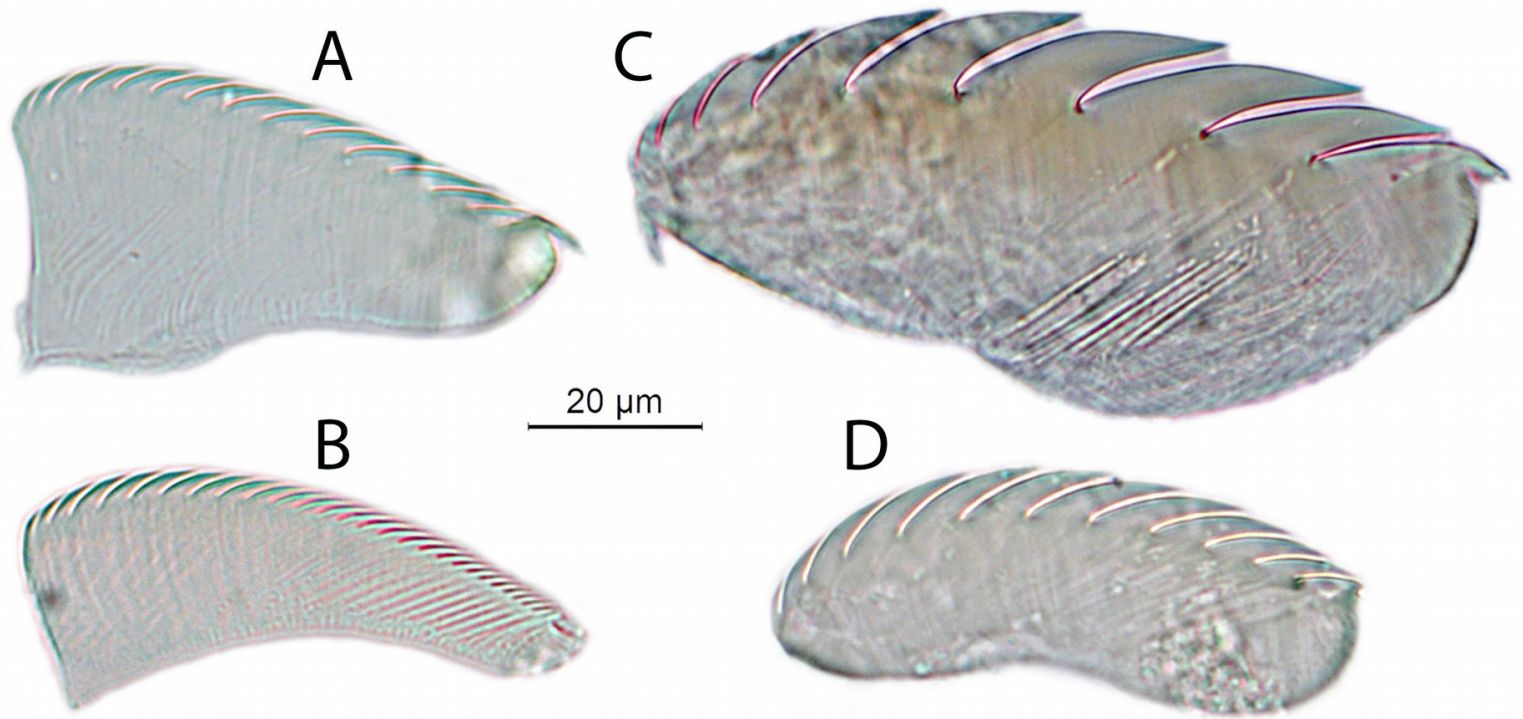

697

698 Figure 3. Uncini from ventral neuropodial tori of region C. Chaetopterus cf. appendiculatus: (A) 699 upper tori; (B) lower tori. Chaetopterus sp.: (C) upper tori; (D) lower tori. 


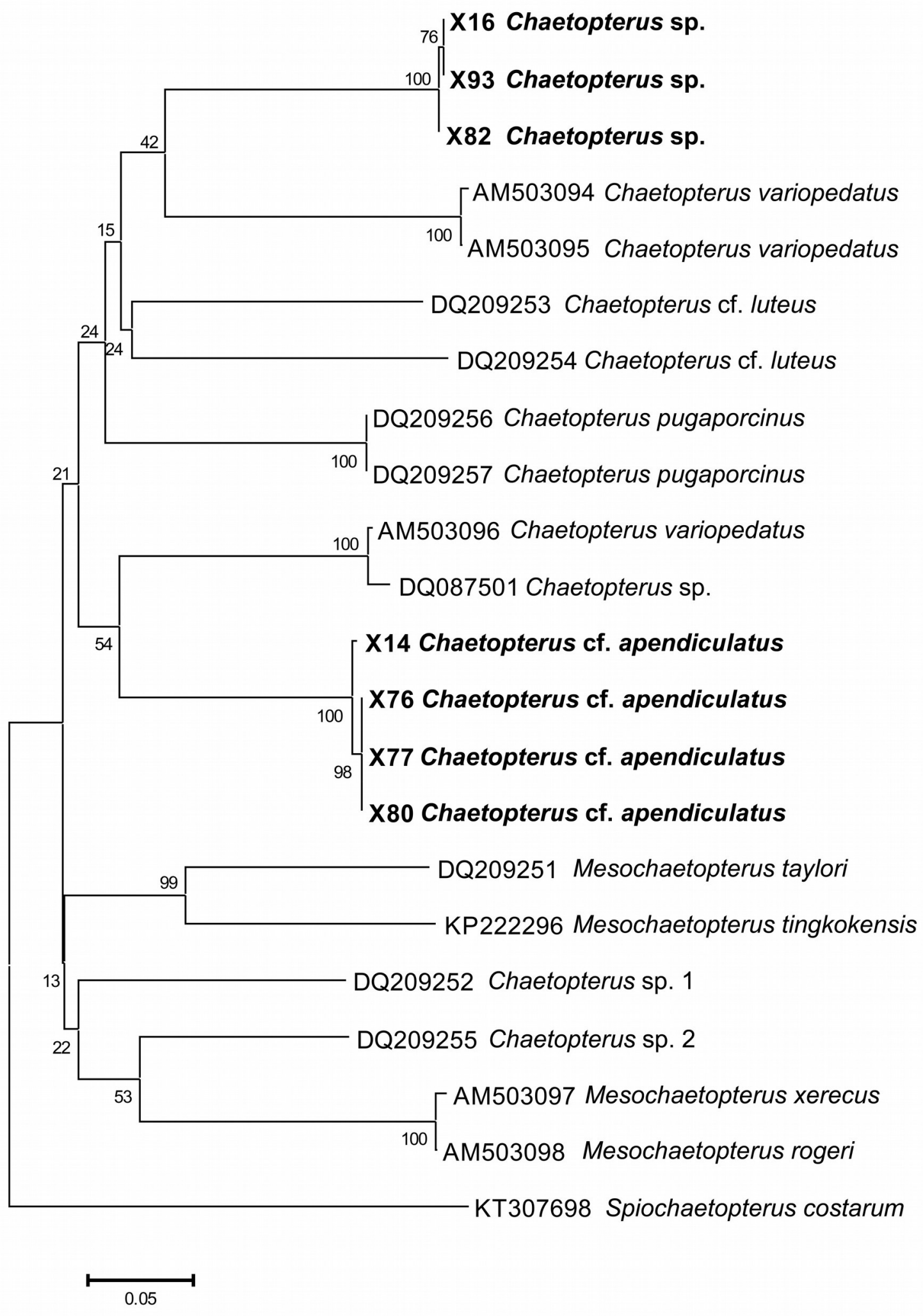

700 Figure 4. Preliminary phylogenetic tree for species of Chaetopterus and Mesochaetopterus based 701 on the COI sequences obtained from NCBI GenBank and our data (in bold). The sequences for 702 the two Vietnamese species are listed in Table 2. 


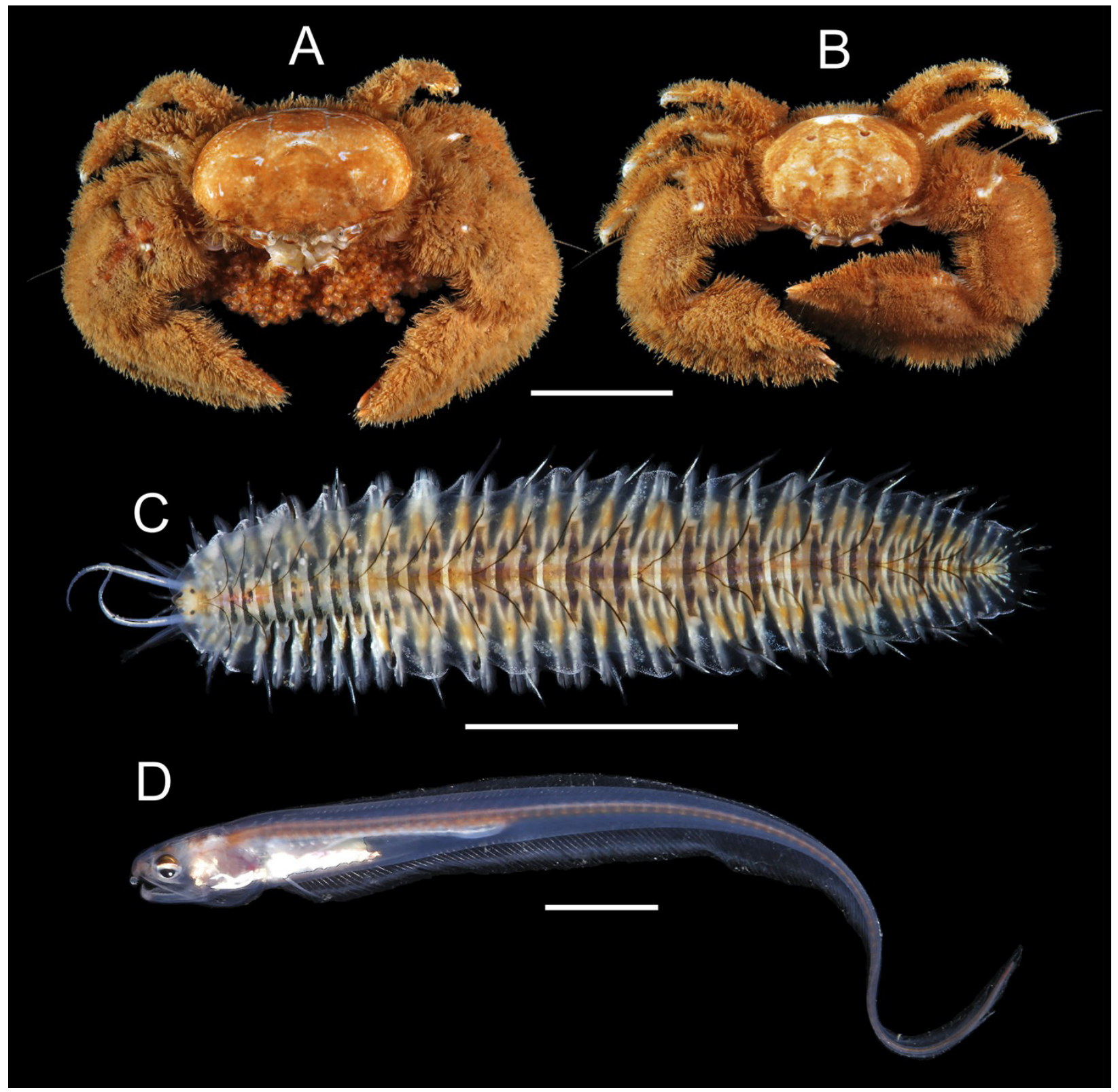

703 Figure 5. Symbiotic community associated with Chaetopterus cf. appendiculatus: (A, B)

704 Eulenaios cometes (female and male, respectively); (C) Ophthalmonoe pettibonneae; (D)

705 Onuxodon fowleri. Scale bars are $1 \mathrm{~cm}$. 

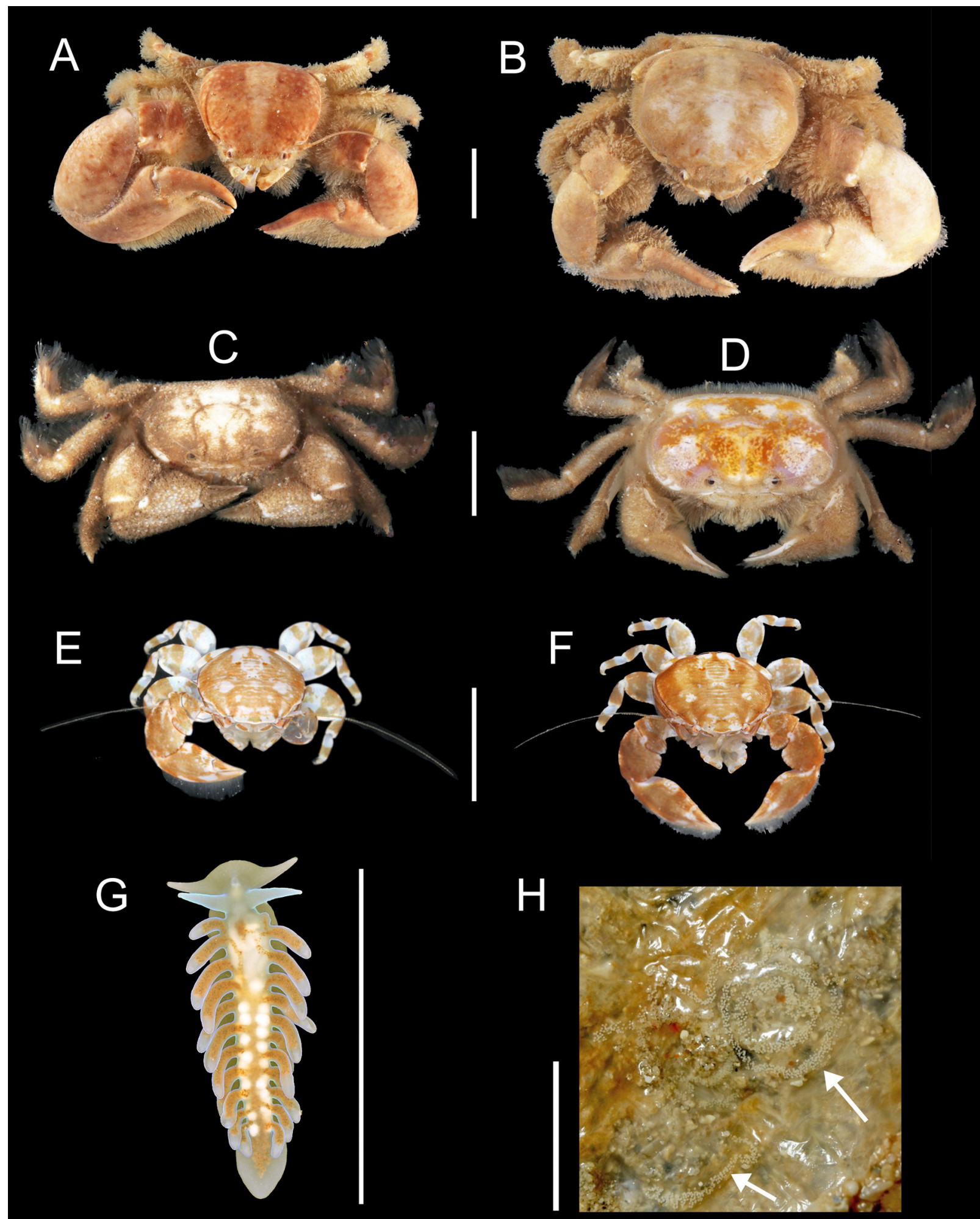

706 Figure 6. Symbiotic community associated with Chaetopterus sp.: (A, B) Polyonyx cf. heox (male 707 and female, respectively); (C, D) Tetrias sp. (male and female, respectively); (E, F) Polyonyx sp., 
708 (male and female, respectively); (G, F) Phestilla sp. (whole body and egg-mass, respectively); 709 egg-mass indicated by arrows. Scale bars are $0.5 \mathrm{~cm}$. 

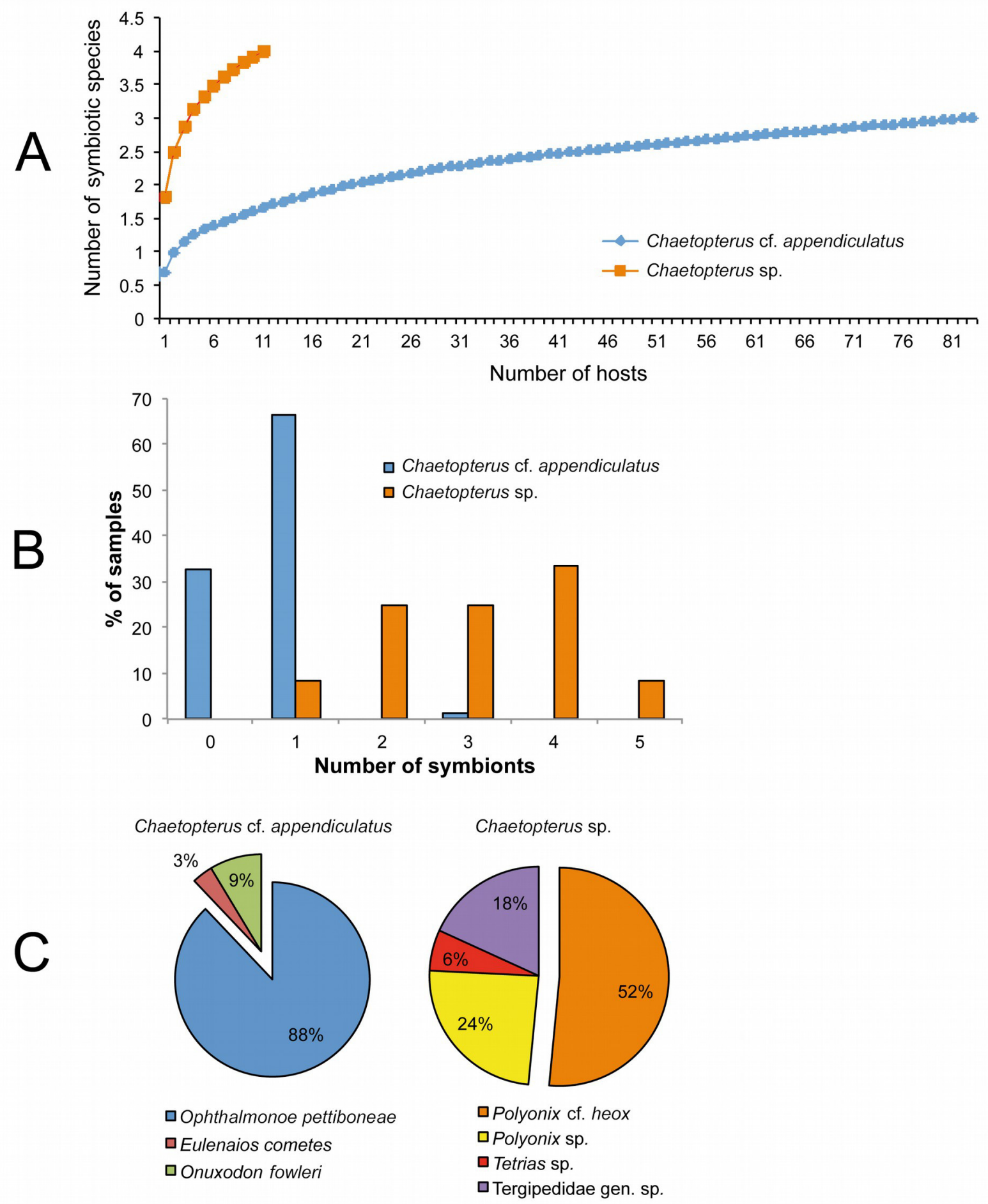

710 Figure 7. Characterization of the symbiotic assemblages associated with the two host species of

711 Chaetopterus: (A) rarefaction curve; (B) distribution of symbionts per host; (C) relative

712 abundance of the symbiotic species. 